\title{
Correction: Oleanolic acid enhances neural stem cell migration, proliferation and differentiation in vitro by inhibiting GSK3 $\beta$ activity
}

Shi Qing Zhang, Kai Li Lin, Cheuk Yu Law, Bin Liu, Xiu Qiong Fu, Wing Sze Tse, Samantha Sze Man Wong, Stephen Cho Wing Sze and Ken Kin Lam Yung

(c) The Author(s) 2021

Cell Death Discovery (2021)7:303; https://doi.org/10.1038/s41420-021-00565-2

Correction to: Cell Death Discovery https://doi.org/10.1038/s41420018-0111-0, published online 15 October 2018

The original version of this article unfortunately contained errors in Fig. 3c. The immunofluorescence images of Nestin and MAP2 were accidentally used in Ctr and OA $20 \mu \mathrm{M}$ groups. The corrected images are provided below. The authors confirm that these errors do not affect the scientific conclusions of the article and apologize for any inconvenience caused.

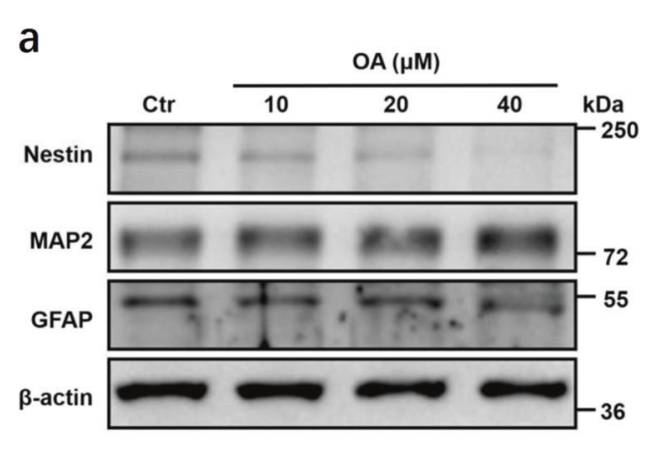

C

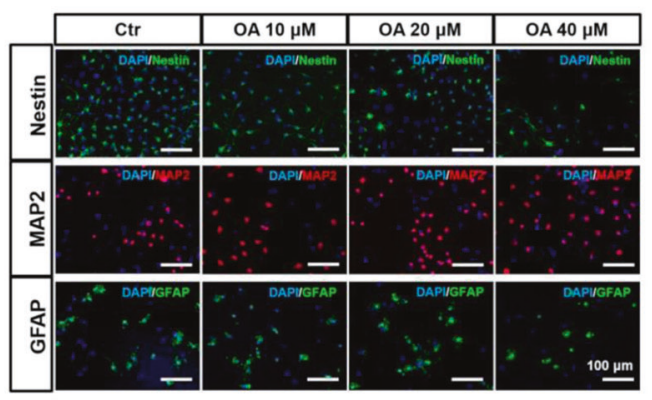

\begin{abstract}
(i) Open Access This article is licensed under a Creative Commons Attribution 4.0 International License, which permits use, sharing, adaptation, distribution and reproduction in any medium or format, as long as you give appropriate credit to the original author(s) and the source, provide a link to the Creative Commons license, and indicate if changes were made. The images or other third party material in this article are included in the article's Creative Commons license, unless indicated otherwise in a credit line to the material. If material is not included in the article's Creative Commons license and your intended use is not permitted by statutory regulation or exceeds the permitted use, you will need to obtain permission directly from the copyright holder. To view a copy of this license, visit http://creativecommons. org/licenses/by/4.0/.
\end{abstract}

(C) The Author(s) 2021

b

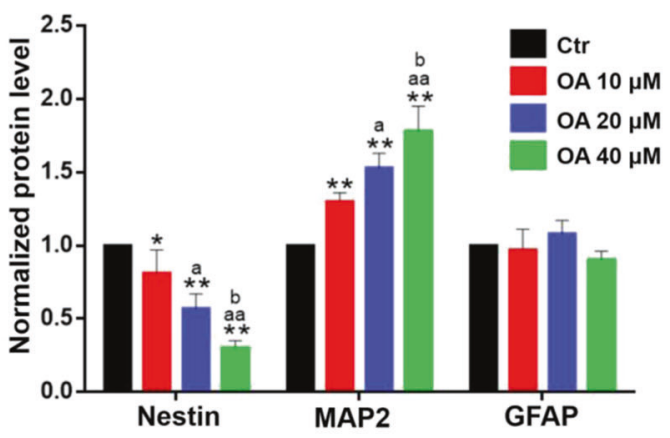

d

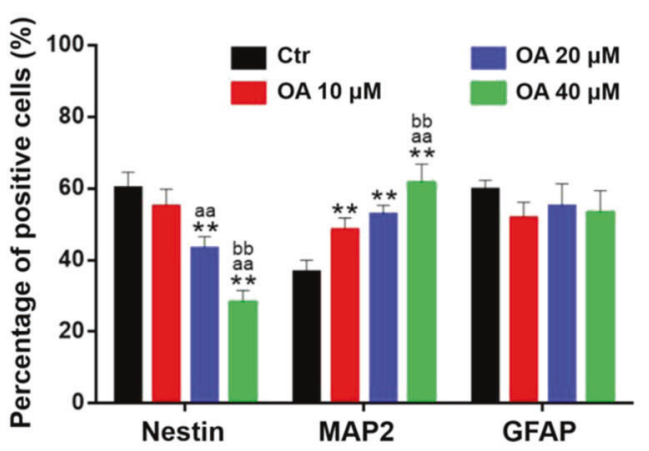

Fig. 3. 